\title{
Information Sharing and Competition in the Motor Vehicle Industry
}

\author{
Maura P. Doyle* \\ Federal Reserve Board \\ Christopher M.Snyder** \\ George Washington Universit
}

December 19,1996

\begin{abstract}
Up to six months ahead of actual production, U.S. automakers announce plans for their monthly domestic production of cars. A leading industry trade journal publishes the initial plan and then a series of revisions leading up to the month in question. We analyze a panel data set spanning the years 1965-1995, matching the production forecasts with data for actual monthly production. We show that a firm's plan announcement affects competitors' later revisions of their own plans and eventual production. The interaction appears to be complementary-large plans or upward revisions cause competitors to revise plans upward and increase production. The results are consistent with models in which firms share information about common demand parameters.
\end{abstract}

JEL codes: L13, D82

*Federal Reserve Board of Governors, Washington D.C. 20551 (email: mdoyle@frb.gov).

** Department of Economics, George Washington University; Washington D.C. 20052 (email: csnyder@gwis2.circ.gwu.edu).

We are grateful to J ohn Kwoka, J ames Seabolt and seminar participants at George Washington University and the U.S. Census Bureau Center for Economic Studies for helpful discussions and to J onathan Reiss for research assistance. The conclusions expressed herein do not necessarily represent the views of the Federal Reserve Board of Governors. We retain responsibility for errors. 


\section{Introduction}

Publishing information regarding firms' costs, demand, outputs, prices or plans for capacity expansion is a common practice in many industries. The information releases may include historical levels or forecasts of future levels and may include industry aggregates or firm-level data. For example, the lumber, coal and steel industries all have associations that provide information on weekly production for the industry. The motor vehicle and aircraft industries publicly announce schedules of future production. Whether published in the business press or more specialized trade journals, the information releases are often accessible to a firms' investors, employees, and customers. It is of particular interest that the information releases are available to competitors.

The economics literature contains two different views on the motives for information sharing among competitors. ${ }^{1}$ One view is that that firms faced with demand or cost uncertainty may be better able to tailor their output or pricing decisions to actual market conditions if they have access to competitors' signals as well as their own private signals. In a model proposed by Novshek and Sonnenschein (1982) and analyzed in a score of later papers, information sharing among competitors can be shown to enhance social welfare in a variety of instances. A contrasting view is that information sharing among competitors can faciliate collusion. In the model of Green and Porter (1984), firms cannot distinguish whether a low realized price was due to exogenous demand fluctuations or due to rivals' undercutting. I nformation about rivals' past actions would allow firms to avoid indiscriminate price wars by punishing only if undercutting was observed.

Whether information sharing produces welfare improvements through efficiency gains or welfare losses through anticompetitive coordination is a question of considerable interest

to antitrust authorities. Scherer and Ross (1990,p.347-352) note that legal precedent in the U.S. is less than clear, citing the American Column and Lumber, Maple Flooring, and Container Corporation cases. In an interesting recent case, several airlines were enjoined

\footnotetext{
${ }^{1}$ See Kühn and Vives (1994) for a Survey of the literature.
} 
from issuing price pre-announcements though the Computer Reservation System as part of the 1994 settlement of U.S.v. Airline Tariff Publishing Company.

Given that theory provides competing theoretical views of information exchange and given that the issue remains controversial in the realm of antitrust policy, there has been surprisingly little formal econometric work on information sharing among firms. Ellison (1994) provides evidence that members of the J oint Executive Committee railroad cartel may have used trigger strategies as hypothesized by Green and Porter (1984), indirect evidence that information sharing would have been useful to aid collusion among the firms. There are also a number of experimental studies on information sharing and price pre-announcement including Grether and Plott (1984), Cason (1994), and Cason and Davis (1995). To our knowledge, the only paper that studies information sharing directly using industry data is Christensen and Caves (1996). They study the announcement of new capacity expansions by pulp and paper firms and the subsequent abandonment of these projects. The likelihood that capacity expansions are abandoned is negatively related to concentration in the submarket, certainty of the project, and internal resources of the firm. They provide some evidence of strategic announcement effects: a rival's subsequent announcement of capacity expansion increases the likelihood that a firm abandons its previously-announced project. $^{2}$

The present paper is an empirical examination of information sharing and its effect on the strategic interaction between the largest U.S. automakers. The motor vehicle industry is a useful one for studying information exchange for several reasons besides its abundance of data. The industry has often been the object of empirical industrial organization studies as it is considered a classic oligopoly. It is also an important industry because performance in this sector has a non-trivial impact on the overall health of the economy.

The major domestic manufacturers of cars--General Motors, Ford, Chrysler, and American Mot ors have exchanged a variety of forms of information through the trade press and

\footnotetext{
${ }^{2}$ This result is true in competitive markets only; the authors find the opposite result in concentrated submarkets.
} 
other media. The information exchanged includes sales, inventories, production, planned overtime, and plant closings. The present study analyzes on one particular form of information exchange, namely the exchange of production plans issued in advance of actual production. From before 1965 to the present, the automakers have pursued a policy of announcing their plans for monthly U.S. production of cars and trucks as early as six months before actual production. These plans are subject to continuous revision until the end of the target month.

We are interested in understanding why firms issue these announcements and how rivals react to them. Do firms simply disregard rivals' announcements as "cheap talk" in a "babbling equilibrium"? If firms do respond to rivals' announcements, what is the direction of the response?

Determining the direction and pattern of firms responses will allow us to assess the empirical relevance of a number of theories of oligopoly information sharing. These theoriesincluding the models of Novshek and Sonnenschein (1982) and the subsequent literature, as well as various models of collusion facilitation-are briefly outlined in Section 2. Section 4.1 presents a detailed discussion of the empirical implications of a representative model from the oligopoly information sharing literature, an extension of $\operatorname{Li}(1985)$.

The main empirical results are presented in Sections 4.2 and 5.1. To summarize, we find that automakers' announcements of production plans do affect market outcomes and are therefore not "babble." Firms' revisions of their earlier production plans, as well as their actual production, respond to signals from their rivals. Specifically, rival firms tend to adjust their production upward in response to an announcement of aggressive production. The particular pattern of responses appsars to depend on which is a given firms' closest rival. We observe interactions between the two largest firms, GM and Ford, as well as an interaction between Chrysler and Ford. We do not observe a relationship between GM and Chrysler based on the signal exchange. In Section 5.2 we examine periods during which an automaker is struck by the UAW-essentially a firm-specific signal of low production. With this type of signal, rivals produce more aggressively than previously planned, the 
opposite of what happens when a firm responds to a low production plan announcement of a rival. The results are consistent with the model proposed in Section 4.1 that the plan announcements contain information concerning an uncertain common demand parameter. The evidence is inconsistent with a model of information sharing concerning idiosyncratic cost parameters and is at best mixed regarding theories of collusion-facilitating communication.

\section{Hypotheses}

The fact that we are focusing on a particular form of information exchange in a particular industry-namely the publication of production-plan announcements by U.S.-limits the set of viable hypotheses explaining why firms share this particular piece of information. For instance, sharing production plans would not aid collusion in a Green and Porter (1984) model since the plans provide no information about past price cutting, so the plans do not help in sorting exogenous demand shocks from undercutting. Reliable information on past production or past sales would aid collusion, and such information is in fact exchanged in many industries including motor vehicles. ${ }^{3}$

We take as the null the hypothesis th.tt firms are non-strategic in their plan announcements, meaning that firms' plan announcements and production decisions do not respond to rivals' earlier signals. This might be so for several reasons. For example, the literature on "cheap talk" suggests that in cases of information exchange without commitment, "babbling" is always a possible equilibrium. ${ }^{4}$ For example, the firms may not undertake the expense of planning future production when polled by Ward's, or may simply issue a random number in order to keep their plans secret. The "cheap talk" models generally establish that costless inaccurate announcements will be ignored and have no influence on

\footnotetext{
${ }^{3} \mathrm{~A}$ higher frequency of information exchange is expected to facilitate collusion, making the motor vehicle industry's cessation in 1992 of the exchange of ten-day sales noteworthy.

${ }^{4}$ The seminal article $i_{n}$ the literature on cheap talk is Crawford and Sobel(1982). For a recent survey of the literature, see Farrell and Rabin (1996).
} 
market outcomes.

Much of the theoretical literature on oligopoly information sharing (Novshek and Sonnenschein (1982) and the later papers) has abstracted from the question of accuracy by assuming that some mechanism exists (for example, an independent auditor) to certify that the information is truthful. Ziv (1993) points out that without such mechanisms, information-sharing equilibria are often unstable. In many practical situations, including the announcement of production plans by U.S. automakers, there exists no such certification mechanism. It is possible that in a repeated game, information may gain credibility if firms are inclined to maintain reputations for honesty. At a fundamental level, then, it remains an empirical question whether the automakers' announcements are regarded as babble or have an real impact on rivals' strategies such as output decisions.

Another rationale for the null hypothesis is that the plans reflect communication within the firm rather than among competitors, perhaps reflecting upper-level management production targets for plant managers to attain. In this equilibrium, we would expect that rivals would not respond to a firm's announcement.

The alternatives to the null involve strategic behavior among firms; i.e., firms' announcements influence competitors' subsequent announcements and production decisions. Whether plan announcements have strategic value will be the subject of empirical study in Section 4. It is noteworthy that Ward's itself suggests the plans may have strategic value: "July-September output planning is too preliminary at this early point to serve as a basis for [solid] projections, but it does provide deep insights into best company thinking at this time and marketing strategy..." ( Ward's Automotive Report, J uly 20,1981).

One set of alternatives is that the production plans allow firms to share information about demand and cost parameters in the spirit of Novshek and Sonnenschein (1982), Clarke (1983), Vives (1984), Gal-Or (1985), Shapiro (1986), and score of other static models cited in Kuhn and Vives(1992). To make the discussion of these models more concrete, assume that competition is characterized by Cournot competition in close substitutes. This assumption is reasonable given Berndt, Friedlaender, and Chiang's (1990) finding that they 
could not reject Cournot quantity-setting behavior in the motor vehicle industry. These assumptions are also realistic in the present context since the focus is on automakers' choice of production levels.

There are three broad effects of information exchange in these models. First, from competitors' reports, firms may learn more about their own uncertain demand and cost parameters. This would be true if there is correlation among the parameters across firms. Second, firms learn more about their competitors' parameters, and thus indirectl $\mathrm{y}_{\mathrm{y}}$ about competitors' likely production decisions. Finally, information exchange may increase or decrease the correlation among competitors' production decisions.

Though there are many possible variants and subcases within each variant to consider, some consistent conclusions do emerge in a Cournot model of information exchange with Cournot competition. If firms share information concerning common demand or cost parameters, information sharing would tend to increase the correlation among their strat egies. In this case, if a firm announced a production expansion, we would expect its rivals to soon follow with their own increases. If firms share information concerning idiosyncratic parameters, information sharing would tend to decrease correlation among their strategies. In this case, if a firm announced a production expansion, it would be an aggressive announcement and we would expect that rivals would reduce planned production. In the empirical work we will seek to distinguish between these two broad patterns of information exchange. In Section 4, we present a version of these models that facilitates the interpretation of the empirical results.

Another set of alternatives is that information sharing facilitates collusion by aiding oligopolists-which because they are heterogeneous may prefer different collusive equilibria in coordinating on a sub-competitive output levels. The strong form of this hypothesis is that an announcement functions almost as Stackelberg commitment to a certain output level. The commitment could arise over time due to a reputation for honesty, or could arise due to the disciplining of an industry leader. A weaker form of this hypothesis is that the announcements represent a complex form of communication among firms, reminiscent 
of (but necessarily cruder than) the airlines' communication via the computer reservation systems. Gertner's (1993) model discussed in the Introduction, falls into this category. It is also possible that firms use the announcements to discipline rivals for apparent deviant behavior such as too-rapid output expansion. Firms could issue warning signals if they consider competitors' production plans to be too high. Rivals could signal understanding by reducing their production plans in response to the warning.

\section{Data}

For this analysis, we will focus on the major U.S. automakers during the period from 1965 to 1995 using data from trade publications. This section presents several tables and charts that highlight the key features of the data.

Table 1 provides several key statistics for the industry broken down into two subperiods, 1965-78 and 1979-95. Monthly industry statistics such as actual production, sales and inventories of domestically-produced cars by the major U.S. automakers (the "Big Four") are compiled from Ward's Automotive Yearbook. Also included is a market share figure, measuring the firm's share total sales of domestically-produced cars. General Motors (GM) is the largest company with 42 percent of the market. Ford ranks second in market share, Chrysler third, and American Motors (AMC) a distant fourth. The ranking of production, sales and inventory is identical. Inventory holdings tend to be two to three times the level of production, and the level of production approximately equals the level of sales. ${ }^{5}$ The standard deviations, listed below the means, indicate that inventory was more variable than production, which in turn was more variable than sales. ${ }^{6}$ Looking across subperiods, there appears to be a decline in production and sales for each of the Big Four, though they are not significantly different. It is particularly notable that the market shares of the

\footnotetext{
${ }^{5}$ The discrepancy between production and sales arises because some domestically-produced cars were sold in other countries (mainly Canada).

${ }^{6}$ For a model explaining th ${ }_{e}$ relative variances of production and sales, see Kahn(1992) and Bresnahan and Ramey (1994).
} 
major U.S. automakers is virtually unchanged between periods despite an increase in U.S. production by foreign-owned plants (known as "transplants").

Data were also collected from the weekly trade journal,Ward's Automotive Reports, on labor strikes causing possible slowdowns in auto production. The data includes both strikes at assembly plants and strikes affecting part supplies and transportation. The table contains two summary statistics relating to strikes. The first statistic is the percent of months in the subperiod during which there was any sort of strike activity for any duration. Strike activity was more prevalent for the larger firm, GM, in both subperiods. Strike activity was more common in the earlier subperiod. The second summary statistic captures the percent of months in the subperiod during which there was a general strike of any duration authorized by the United Auto Workers Union (UAW) against the firm. A general strike involves all the firm's auto assembly plants (as distinct from UAW strikes affecting only a subset of the firm's assembly plants, wildcat strikes, or strikes affecting parts and transportation suppliers). General UAW strike activity also appears to be positively correlated with size. The exception regards American Motors: in the late 1970s, American Motors only operated one plant (Kenosha), so any assembly strike during this period necessarily involved all its plants. It is also noteworthy that general UAW strike activity was concentrated in the 1965 to 1979 subperiod.

Typically, a start date to the strike, an end date, the plants involved, and the units reportedly lost are available from Ward's Automotive Reports. This information was used to create several dummy variables in an attempt to adjust for strike-influenced drops in production. In this version of the paper, we account for strikes using only one of the constructed dummy variables, the one indicating the presence of any strike activity during the month in question. In principle, the data would allow a more precise adjustment for the influence of strikes, an issue we will treat address in subsequent work.

The main variable of interest, collected from Ward's Automotive Reports, is the announcement of planned production. Regular contact between Ward's and the U.S. automakers results in periodical public announcements of the company's scheduled produc- 
tion. Generally, the schedules, updated on the fourth week of the month, include planned production for the next several months, as well as the current month. Ward's will report schedules more frequently if the companies initiate additional announcements. The companies sometimes refer to these plans by various synonyms: "assembly targets," "assembly schedules," "production plans," "production forecasts," etc. The announcements are either explicit reports by the company or Ward's interpretation of a company's imprecise report. In any event, the schedule represents a figure that the automaker is willing to release to the public. These announcements may be issued as much as six months ahead of actual production. Revised announcements are released periodically up to the last day of the production month in question. In some instances, revisions are issued even after the last day of the month.

Since the structure of the data set is slightly complicated, it will prove useful to set out some formal notation for the variables in the data set. Let $\tilde{Q}_{i t}(\theta)$ be the announcement by firm $i$ at date $\theta$ of its production in the month ending on date $t$. There may be several announcement dates associated with any production date. Let $\Theta_{t}$ be $t_{e}$ set of these announcement dates; i.e., $\Theta_{t} \equiv\left\{\theta Q_{i t}(\theta)\right.$ issued $\}$. In principle, $\Theta_{t}$ could differ across firms, but in practice Ward's publishes plan announcements on the same dates. Let $\theta_{t}^{k}$ be the $k$ th lowest element of $\Theta_{t}$. Define $P_{i t}^{k} \equiv \tilde{Q}_{i t}\left(\theta_{t}^{k}\right)$, the $k$ th announcement issued by firm $i$ for its production in the month ending at date $t$. In short, $P_{i t}^{k}$ is firm i's $k$ th production plan. Note there are $\# \Theta_{t}$ such plans for each production date $t(\# X$ is the number of elements in set X). Each plan is associated with an horizon, the elapsed time in days between the issuing of the plan and the end of the production month. Let $H_{t}^{k}$ denote the horizon associated with plan $P_{i t}^{k}$;i.e., $H_{t}^{k}=t-\theta_{t}^{k}$. Denote the $k$ th revision of firm $i$ 's announcement by $R_{i t}^{k}$; i.e, $R_{i t}^{k} \equiv P_{i t}^{k+1}-P_{i t}^{k}$. Though the term "horizon" was Originally defined as a property of a production plan, abusing notation slightly, we will sometimes refer to $H_{t}^{k}$ as the horizon associated with revision $R_{i t}^{k}$. Denote the $k$ th cumulative revision of firm i's announcement by $C R_{i t}^{k}$; i.e., $C R_{i t}^{k} \equiv P_{i t}^{k+1}-P_{i t}^{1}$. Note there are $\# \Theta_{t}-1$ such revisions for each production date $t$. 
An example may serve to illustrate the structure of the data set. Consider the sequence of production plans for the month of June, 1974 (randomly selected from the data set), presented in Figure 1. For this particular month, there were five production-plan announcements, the first on March 4 (production plan $P^{1}$, issued four months before total output for the month of $J$ une was realized) and the fifth on $J$ une 3 (production plan $P^{5}$, issued several days after production had begun in J une but before total output was realized). The first revision, $R^{1}$, is the difference between the March 15 and the March 4 production plans.

Much of the analysis will focus on systematic deviations of the production plans from actual production, in other words, errors in the production plans. We measure production plan errors in two ways, in levels and in percentage terms. Let $P P E_{i t}^{k} \equiv Q_{i t}-P_{i t}^{k}$ be the error level and

$$
Z P P E_{i t}^{k} \equiv 100\left[\frac{Q_{i t}-P_{i t}^{k}}{\frac{1}{2}\left(Q_{i t}+P_{i t}^{k}\right)}\right]
$$

the error percentage of the $k$ th product ion plan. The latter measure is expressed as a percentage of the average of the actual level and the plan. As an accounting convention, the measures are negative if the firm overstates its actual production, or in the jargon of the trade press, if the firm "underbuilds."

The pattern of errors in production plans, by company, is shown in Figure 2. The errors tend to lie below the horizontal axis, indicating that the plans tend to overestimate actual production. In addition, the errors tend to be more dispersed the farther the plans are made in advance of the production date. This pattern is true for all firms, but particularly so for GM. Some overestimation would be expected, as the auto industry occassionally faces sudden negative shocks to production, including bad weather, parts shortages and strikes. The fact that errors appear smaller as the horizon gets shorter suggests that companies do announce more accurate schedules with more information, suggesting that the schedules have more accurate information as one gets closer to production time. However, even after the conclusion of the month in question, plan errors can differ from zero. Figure 3 pools the data across firms, dividing the data instead by time periods. Similar patterns in the 
errors are apparent across time periods. One feature of note is that the observations tend to occur in bunches along the horizontal axis in the last subperiod(1985-95), indicating that the announcements of production plans were made at more systematic intervals in the recent past than before.

Table 2 confirms the impressions from the figures: the means of the production plan errors are negative and become increasingly negative as the horizon increases until the horizon reaches about two months. The standard deviations grow with the horizon as well. GM has the largest production plan errors in absolute terms ( $P P E)$. In percentage terms ( $Z P P E)$, only American Motors has larger errors. ${ }^{7}$ Nonetheless, in percentage terms, the errors of the Big Three do not appear substantially different. As the table shows, there are a substantial number of observations in each firm/horizon cell, and over 1,000 observations per firm for a total of nearly 7,000 observations of production plans (and therefore production plan errors) in the data set.

\section{Tests of Information Sharing}

In our empirical analysis, we examine information sharing in the auto industry with several different approachs. First, we examine the relationship between the announcement of production plans and actual production. Second, we examine the relationship between early announcements of production plans and subsequent revisions. Finally, we examine the response of an automaker to an idiosyncratic shock to a rival in the form of a strike.

\subsection{Model}

In this section, we adapt Li's (1985) model of information sharing to the context of the motor vehicle industry. Suppose there are $n$ firms which for simplicity produce a homogeneous product at marginal cost $c$. Demand in a given period, labeled period $t$, is linear:

\footnotetext{
${ }^{7}$ This could be due $i_{n}$ part to rounding: American Motor's plans are typically rounded to the nearest thousand; its actual production levels are not. For production levels in the 10,000 range, for example, rounding could generate errors as high as five percent.
} 
$p_{t}\left(Q_{t}\right)=$ at $+\gamma_{t}-b_{t} Q_{t}$, where $a_{t}, b_{t}$ are positiveconstants, $Q_{t}$ is industry output in period $t$ and $\gamma_{t}$ is a mean-zero random variable with density function $g_{t}\left(\gamma_{t}\right)$. In this model, the only source of uncertainty is a demand intercept, common across firms. Firms engage in simultaneous quantity competition in period $t$.

Prior to product-market competition in period $t$, each firm $i$ is assumed to obtain a signal, $s_{i t}$, of $\gamma_{t}$ which it may share with competitors. To focus on the consequences of truthful information sharing, we shall assume that firms credibly reveal their signals to each other. (This model is less general than Li's, in which firms are allowed to announce garbled signals of their private information.) In the absence of a mechanism for credible information revelation, we assume that the reputation for honest revelation is sufficiently valuable to maintain honesty. Let $\tau_{i}$ be the precision of $s_{i} t$-i.e., $\tau_{i} \equiv 1 / \mathrm{E}\left[\operatorname{Var}\left(s_{i t} \mid \gamma\right)\right]$ - and let $\tau_{\gamma}$ be the precision of firms' priors concerning $\gamma$-i.e., $\tau_{\gamma} \equiv 1 / \operatorname{Var}(\gamma)$.

Under the assumptions that (1) firms' signals are unbiased estimators of $\gamma$ and (2) firms' expectations of $\gamma$ conditional on $\left\{s_{i t}\right\}_{i=1, \ldots, n}$ are a linear combination of these signals, it can be shown as a corollary to Li's Proposition 1 that the unique Bayesian equilibrium involves the following output strategy for firm z:

$$
Q_{i t}=\xi_{0}+\sum_{j=1}^{n} \xi_{j}^{i} s_{i t}
$$

where $\xi_{j}^{i}>0$ for $j \neq i$. In sum, if firms share information about a common demand parameter, their best-response functions (output as a function of competitors' signals) will be strictly increasing. ${ }^{8}$ In general, $\xi_{j}^{i}$, the partial derivative of firm $i$ 's best-response function with respect to firm $j$ 's signal, differs across $j$. It can be shown, for example, that

${ }^{8}$ Deriving $t$ his result from proposition 1 of $\operatorname{Li}(1985)$ requires two steps. First, under the assumption maintained here that firms truthfully and completely reveal their private information, it can be shown that the expression labeled $\delta_{i}$ in $\mathrm{Li}$ is positive and constant across $i$. It can then be shown using an expression from Li's proof of Proposition 1 that $\xi_{j}^{i}$ has the same sign as $(n+1) \delta_{i}-\sum_{i=1}^{n} \delta_{j}=(n+1) \delta_{i}-n \delta_{i}=\delta_{i}>0$.

One drawback of applying Li's model to the present context is that firms' expected profits fall if they share information. This result disappears if marginal costs are increasing (Kirby 1988), if competition is in prices (Vives 1984), or if the uncertainty regards the demand slope rather than the intercept (Maleug and Tsutsui 1996). 
$\xi_{j}^{i}$ increases with $\tau_{j}$, the precision of $j$ 's private signal.

The model needs to be modified in two respects to better fit the case of the motor-vehicle industry. First, in practice, auto producers announce quantities rather than demand intercepts. To account for this fact we shall assume that, given a production-plan announcement $P_{j t}$ by firm $j$, all other firms $i \neq j$ can infer the associated private signal for $j$. That is, there exists a strictly-increasing function, $s_{j t}\left(P_{j t}\right)$, mapping plan announcements into underlying signals. We assume, further, that this function is common knowledge.

A second modification is needed because, in practice, auto producers share multiple production-plan announcements for any given production month $t$ rather than just one announcement. We model the motive for multiple announcements as stemming from gradual learning about the state of demand. More formally, rather than receiving a single signal $s_{i t}$ of $\gamma_{t}$, firm $i$ ma receive a sequence of signals $\left\{s_{i t}^{k}\right\}_{k=1, \ldots, \# \Theta_{t}}$, which it shares with competitors before production in month $t$. (Recall that $\# \Theta_{t}$ is the number of plan announcements associated with production in month $t$.) During each stage of the revision process, a firm incorporates any new information into its new production plan announcement. As before, let $P_{i t}^{k}$ be firm i's $k$ th production plan for month $t$ and let $R_{i t}^{k-1}=P_{i t}^{k}-P_{i t}^{k-1}$. Firm i's revised production plan is given by

$$
P_{i t}^{k+1}=f_{i}\left(P_{i t}^{k},\left\{s_{j t}^{k}\left(R_{j t}^{k-1}\right)\right\}_{j \neq i}, s_{i t}^{k+1}\right)
$$

The revised production plan depends on firm i's previous plan, which incorporates information before the $k$ th announcement, in addition to information firm $i$ obtains between its $k$ th and $k+1$ st announcements. This new information includes two pieces: rivals $k$ th announcements (made contemporaneously with firm i's $k$ th announcement) and firm i's new private signal, $s_{i t}^{k+1}$. Similar to the formalization in the previous paragraph, firm $i$ does not receive competitor $j$ 's signal directly; firm $i$ infers $j$ 's new signal from the revision in $j$ 's production plan, $R_{j t}^{k-1}$, the inference embodied in the strictly increasing function $s_{j t}^{k}\left(R_{j t}^{k-1}\right)$. A first-order Taylor approximation of (2) gives the following linearized form for 
the best-response function:

$$
P_{i t}^{k+1}=\alpha_{0}+\alpha_{i} P_{i t}^{k}+\sum_{j \neq i} \alpha_{j} R_{j t}^{k-1}+\beta_{i} s_{i t}^{k+1}+u_{i t}^{k+1}
$$

where $\alpha_{j}=\left(\partial f_{i} / \partial s_{j t}^{k}\right)\left(d s_{j t}^{k} / d R_{j t}^{k-1}\right)$. Similar to the proof above that $\xi_{j}^{\imath}$ in equation (1) is positive, it can be argued that $\partial f_{i} / \partial s_{j t}^{k}>0$. Further, according to the formalization above, $d s_{j t}^{k} / d R_{j t}^{k-1}>0$. Hence $\alpha_{j}>0$. Rearranging (3) so that the left-hand side is a revision rat her than a production plan, for $k \geq 2$ we have

$$
R_{i t}^{k}=\alpha_{0}+\left(\alpha_{i}-1\right) P_{i t}^{k}+\sum_{j \neq i} \alpha_{j} R_{j t}^{k-1}+\beta_{i} s_{i t}^{k+1}+u_{i t}^{k+1}
$$

For $k=1$, the information firm $i$ receives from competitors is embodied in competitors' first production plan (competitors have no previous plan to revise, so $R_{j t}^{k-1}$ is not defined for $k=1)$. In the special case of $k=1$, equation (2) implies ${ }^{9}$

$$
R_{i t}^{1}=\alpha_{0}+\sum_{j \neq i} \alpha_{j} P_{j t}^{1}+\beta_{i} s_{i t}^{2}+u_{i t}^{2}
$$

To summarize, we derived several empirical implications from a model in which firms share information over a period of time concerning a common demand parameter. Firms' behavior can be captured by a sequence of best-response functions exhibiting strategic complement arity: firms tend to revise their plans upward if rivals' previous announcements or revisions were high. The partial derivatives of the best-response functions depend on competitor-specific variables including, for example, the perceived precision of their signals. In practice-since the motor vehicle industry involves differentiated rather than homogeneous products-the partial derivatives may also depend on the closeness of firms' output in the product space.

It is instructive to compare the resul $\mathrm{s}_{\mathrm{s}}$ in a model with uncertainty about a common

\footnotetext{
${ }^{9}$ The superscript 2 on $s_{i t}$ and $u_{i t}$ in equation (5) refer to a number in the plan-announcement sequence, not a power to which the variables are raised.
} 
demand parameter to those from a model with uncertainty about idiosyncratic costs. Consider therefore an alternative model in which each firm $i$ has private information about the level of its constant marginal cost, $c_{i}$. Similar to the derivation of equation (1), it can be shown (see Li(1985), Proposition 6) that firm i's optimal output is increasing in competitors' signals of their own costs. Since auto producers share production-plan announcements rather than directly sharing signals of their marginal costs, to adapt the model to the motor vehicle industry, the next step is to consider how competitors may deduce firm i's signal about its uncertain marginal cost trom $i$ 's production-plan announcement. As before, we will assume there is a monotonic mapping from production plans to signals. In contrast to the model with common demand uncertainty, in the model with idiosyncratic cost uncertainty this mapping is strictly decreasing. That is, a high production plan announcement is correlated with a high demand intercept with common demand uncertainty but is correlated with a low marginal cost with idiosyncratic cost uncertainty.

Thus, the implications for the partial derivatives of a best-response function such as (4) with respect to competitors' announcements differ depending on the source of the uncertainty. Common demand uncertainty implies a strategic complementarity; idiosyncratic cost uncertainty implies a strategic substitutability.

\subsection{Empirical Results}

In this subsection, we present empirical estimates of the best-response functions (4) and (5). The first set of regressions is an empirical implementation of (5). In this set of regressions we estimate how a given firm first revises its production plan in response to information contained in competitors' first production-plan announcements. The dependent variable is thus $R_{i t}^{1}$; the independent variables of interest are $P_{j t}^{1}$ for $j=1, \ldots, n$. For each of the Big Three (GM, Ford, and Chrysler), there are two regressions for each company, one including and one excluding $\mathrm{AMC}$, as the inclusion of AMC limits the span of the study to the mid-eighties after which AMC exited the sample. We allow coefficients to vary across firms; recognizing that the errors may be contemporaneously correlated across firms, the 
method of Seemingly Unrelated Regressions (SUR) is employed. We control for seasonal variation with monthly dummies.

The results, presented in Table 3, show that, except for AMC, firms tend to revise toward the mean. The coefficients for their own initial production plan are negative and significantly different from zero. Specifically, they revise downward a plan that was initially aggressive or revise upward a plan that was weak. This result is consistent with the findings from Figure 3: production plan errors shrink as the horizon shrinks and the firms nears the actual production date.

The coefficients on rival's initial production plans (estimates of $\alpha_{j}$ in equation (5)) are consistent with the model of information sharing about a common demand parameter and inconsistent with the model of information sharing about idiosyncratic costs. Those coefficients that are precisely estimated are significantly positive, indicating that firms' first revisions seem to move in a complementary direction with rivals' initial production plans. In particular, Ford appears to move in response to Chrysler's plans while GM responds to Ford's plans. If firms were sharing information about idiosyncratic costs, we would expect to see non-positive coefficients.

To interpret the magnitudes of the coefficients, consider the coefficient for Ford's initial production in GM's regression excluding AMC, 0.196. This number implies that an increase in Ford's initial production plan of 1,000 cars causes GM to revise its plan upwards by 196 cars. As a rough rule of thumb, the coefficients can be converted into elasticities by multiplying them by the ratio of the rival's to the firm's size ("size" measured in the usual ways: output, sales, etc.). For example, using any measure from Table 1, Ford is about half of GM's size, so the elasticity corresponding to the 0.196 estimate would be approximatel 0.1. Notice that the apparently large (in absolute value) coefficient on AMC's initial plan in GM's regression $(-0.339)$ translates into a small elasticity (approximately -0.02 ) since AMC is only one sixteenth the size of GM.

Other controls included in the regression, the horizon and a constant, are generally not significant. The fact that horizons do not vary greatly across observations included in 
the regression (they are all first revisions often issued a set amount of time before actual production) would explain the lack of significance in the horizon coefficient. The included set of monthly dummies (whose coefficients are not reported) are jointly significant in general, though their exclusion does not substantially affect the coefficients of interest.

The results carry over to the regressions involving revisions later than the first. This second set of seemingly unrelated regressions - essentially an empirical implementation of equation (4) -is reported in Table 4. One difference between (4) and its empirical implementation is that competitors' revisions are included as right-hand side variables in (4) whereas cumulative revisions are included in the empirical implementation. The empirical implementation includes cumulative revisions, $C R_{i t}^{k-1}$, to allow for the possibility of lagged responses. ${ }^{10}$

In Table 4 the dependent variable is a firm's revision of its production plan; but second and later revisions are included, rather than the first revision as in Table 3 . The results are largely consistent with the proposition that firms' best-response functions exhibit a strategic complementarity. Automakers revise their plans upward in response to rivals' cumulative revisions. The pattern of response is similar to that in Table 3. GM responds positively to Ford's revision; Ford to GM's and Chrysler's. Chrysler responds positively to Ford's revision, the effect estimated to be larger and more precisely estimated than in Table 3. The one anomaly in this pattern is Chrysler's negative response to AMC's revision, a marginally significant coefficient of -0.229 . In fact, all firms seem to respond negatively to A MC in both Tables 3 and 4, though the effect is small if measured as an elasticity: for example, the -0.229 coefficient corresponds to an elasticity of approximately $-0.037 .11$

\footnotetext{
${ }^{10}$ Anther minor difference is that the empirical implementation is slightly more general than $(4)$ in that it includes two variables, own cumulative revision $\left(C R_{i t}^{k-1}\right)$ and own initial production plan $\left(P_{i t}^{1}\right)$, in place of a single variable for own past production plan $\left(P_{i t}^{k}\right)$ as in (4). That the empirical implementation is more general than (4) follows from the fact that $P_{i t}^{k}$ is a linear combination of $P_{i t}^{1}$ and $C R_{i t}^{k}$ (true due to the accounting identity $\left.P_{i t}^{k} \equiv P_{i t}^{1}+C R_{i t}^{k-1}\right)$.

${ }^{11}$ In interpreting the results, it should be noted that there is the theoretical possibility of omitted variable bias in the estimation of equation (4) since the researcher does not have data on $s_{i t}^{k+1}$.(Analogous arguments can be made for equation (5)). For the omission of this variable to cause a bias in the estimates of interest, sat $^{k+1}$ would have to be correlated with $P_{j t}^{k}$. Such correlation would arise if the information contained in firm
} 


\section{Extensions of the Empirical Analysis}

In this section we examine two extensions of the empirical analysis. In Subsection 5.1, we determine whether a firm's responses to competitors during the revision process are merely "cheap talk" or whether they translate into tangible changes in a firm's output. In Subsection 5.2, we contrast the previous empirical results to the case in which firms obtain an observable signal of rivals' costs (namely, a labor strike)..

\subsection{Production Plans and Output}

Equations (4) and (5), as well as the regression results in Tables 3 and 4, describe how one firm's announcements concerning its anticipated production level vary with competitors' earlier announcements. The question remains whether a firm's actual production also responds to competitors' announcements such as postulated in equation (1). Specifically, we analyze the relationship between a firm's actual production and its own and rivals' production plans made about a month in advance of actual production. The regressions take the following form:

$$
Q_{i t}=c_{i}^{0}+c_{i}^{1} P_{i t}^{k}+\sum_{j \neq i} c_{i j}^{2} P_{j t}^{k}+c_{i}^{3} H_{t}^{k}+\epsilon_{i t}
$$

where the $c$ coefficients are to be estimated and $\epsilon_{i t}$ is an error term. Here, $k$ is chosen so that the associated plan announcement date $\theta_{t}^{k}$ is as close as possible to one month prior to $t$. Coefficients $c_{i j}^{2}$ measure how i's production responds to competitors' plans and are thus the coefficients of interest. We employ the SUR method, allowing coefficients to vary across firms. We also control for seasonal variation with monthly dummies and control for the effects of strikes with a strike dummy equaling one if firm $i$ experiences any strike activity within the given production month.

The coefficient $c_{i}^{1}$ will provide some indication of the "cheapness" of firms' production-

j's announcement were revealed privately to firm $i$ in the interval between date $\theta_{t}^{k}$ and $\theta_{t}^{k+1}$. In practice, it is unlikely that a large amount of information flows to firms according to this precise timing. 
plan announcements. If the production-plan announcements are part of a babbling equilibrium, then we would expect $c_{i}^{1}$ to be zero. We would also expect automakers to ignore rival's signals and, consequently, we would expect $c_{i j}^{2}$ to be zero. Positive values for $c_{i j}^{2}$ are consistent with the model of information sharing concerning a common demand parameter; negative values are consistent with information sharing concerning idiosyncratic cost parameters.

Table 5 reports the results for the specification described above. As can be seen from the parameter estimates for the firm's own production plan, each company's production is highly correlated with their respective month-ahead announcements and significantly different from zero. Despite the fact that production plans have no commitment value, they do not appear to be simply cheap talk. Thus, information sharing in the auto industry is not a babbling equilibrium. In fact, GM's production rises about one for one with plans: an $F$-test cannot reject that the estimate of $c_{i}^{1}$ equals one for GM. For the other companies, the estimates for $c_{i}^{1}$ are significantly less than one, though still quite high.

Additionally, the results of Table 5 illustrate some of the effects of information sharing: some companies produce more when their rivals plans are high. Again, this supports the notion that automakers do not interpret their rivals' announcements as cheap talk. It is noteworthy that GM appears to not react to any rival plans, as the coefficients for the rival plans of Chrysler, Ford and $\mathrm{AMC}$ are all small and not significantly different from zero. Combined with the previous findings for GM in Tables 3 and 4, the results imply that GM responds to competitors in early revision stages; but once its month-ahead plan is set, GM produces this amount without regard to competitors. Such would be the case if GM's signals of demand were more precise (either because of its leadership position in the industry or because of the expenditure of greater resources on forecasting). This story is consistent with the findings of Bresnahan (1987) and Berndt, Friedlaender, and Chaing (1990), both indicating that GM has a special status in the auto industry (either as a low-cost firm or a quantity leader). In contrast, both Ford and Chrysler react to rival plans. Ford's production depends positively on GM's month-ahead plans, and Chrysler's 
production depends positively on Ford's month ahead-plans. In both cases, the firm is responding positively to its next larger rival. Chrysler appears to respond negatively to GM's plans, but the coefficient is marginally significant and disappears in the regression excluding AMC involving a longer time series.

Of the additional controls included in the regressions, the "own-strike" dummy and monthly dummies are highly significant. We shall defer the discussion of the strike results to Subsection 5.2 .

To summarize, the results from Table 5 are largely consistent with findings from Tables 3 and 4 , all results consistent with a model in which firms share information concerning a common demand parameter. Although the results provide no direct information on the particular pattern of responses (Ford following GM's plans, Chrysler following Ford's), it is plausible that two factors may determine the magnitude of firms' responses to rivals' plans. First, firms may respond more to larger competitors, who may expend a greater absolute amount on forecasting and thus may announce signals of greater precision. Second, in a market with differentiated products, firms may respond more to competitors closer to themselves in the product space since the signals of closer competitors have more relevance. If Chrysler's product line is closer to Ford's, this second factor may explain why Chrysler would respond to Ford's announcements but not GM's.

The results can be used to reject a number of forms of strategic or collusive behavior in the auto industry. One hypothesis offered in Section 2 is that firms use the announcement mechanism to become a sort of Stackelberg leader, issuing aggressive plan announcements to cause followers to restrict their output. Given the empirical findings, such behavior would have the opposite of the intended result, causing followers to expand their output. Another hypothesis is that firms use the announcements as a disciplining device;i.e., firms warn competitors of unacceptable behavior by threats of increased output causing firms to return to some collusive output level. In practice, GM is firm most likely to use such a disciplining device. GM's revisions respond positively to competitors' earlier announcements, consistent with a warning signal; however, there is little evidence that firms reduce 
their plans in response to GM's warning signals. Further, GM's actual production level does not respond to competitors' actions. Thus, the evidence is at best mixed regarding the disciplining-device hypothesis.

\subsection{Production and Signals of Idiosyncratic Costs}

In the previous sections, we examined the response of automakers to signals in the form of announced production plans. The results have suggested that these announcements are signals of some common demand parameter. In this section, we examine a signal that is known to be firm-specific, UAW strikes. We consider a strike to be a signal that the affected firm is temporarily experiencing a production setback that is analogous to extremely high costs of production. In the case of a complete shutdown, costs could be considered infinite. A firm may not want to send a signal that they are in a high-cost phase, but the publicity of a strike is unavoidable.

The focus of this subsection therefore is on a firm's response to rivals'strikes. We use the SUR methodology to estimate a system of regressions of the following form:

$$
P P E_{i t}^{k}=d_{i}^{0}+d_{i}^{1} S T R I K E_{i t}+\sum_{j \neq i} d_{i j}^{2} S T R I K E_{j t}+d_{i}^{3} H_{t}^{k}+d_{i}^{4}\left(H_{t}^{k}\right)^{2}+d_{i}^{5} P_{i t}^{1}+\nu_{i t}^{k}
$$

where the $d$ are coefficients to be estimated, STRIKE $E_{i t}$ is a dummy indicating that firm $i$ faced a strike at an assembly plant some time during production month $t$, and $\nu_{i t}^{k}$ is an error term. The dependent variable is the error associated with the $k$ th production plan, defined in Section 3. The independent variables include strikes (both own and competitors)), two powers of the horizon, and the initial plan level $P_{i t}^{1}$. We specified a quadratic function of horizon since Figures 2 and 3 suggested that horizon might be an important determinant of errors.

The estimates for $d_{i}^{1}$ ("own strike") reported in Table 6 demonstrate that the UAW strike effectively cuts production relative to the company's plan. The coefficients are negative in all cases and significant in all cases save for the regression for Chrysler including 
AMC. Strikes caused GM to fall short of its production plans by over 13,000 cars, Ford by about 34,000 , and Chrysler by over 2,000. Given that $S T R I K E_{i t}$ is simply a $0-1$ indicator and does not distinguish between severe strikes (e.g., involving all assembly plants for the entire month) and small ones (e.g., one plant for a week), these estimates understate the effect of the severe strikes.

The general tenor of the results from Table 6 is that a rival produces more than planned when a competitor is hindered by a strike. The findings suggest that a firm boosts production when it observes a rival's production setback. Ford, Chrysler and AMC produce more when GM is affected by a strike. GM also takes advantage of Ford when Ford is struck. Firms do not respond significantly to strikes affecting Chrysler, though the fact that the coefficient on "own strike" in the regression for Chrysler is only marginally significant indicates that many of the strikes facing Chrysler were probably not severe. This explanation is supported by Table 1, which shows that, of the Big Four, Chrysler endured the fewest months of strikes involving the closure of all assembly plants (general UAW strikes). The negative and significant coefficient on AMC's strikes in Chrysler's regression presents a puzzle. One explanation would be, given the close ties between the firms especially in the mid-eighties, strikes at AMC may have been correlated with labor unrest short of strikes at Chrysler.

The results from Table 6 show that firms expand output when they receive a signal about a rival-such as a strike-indicating that the rival will likely cut back production. This pattern of responses is exactly what is predicted by the model of information sharing concerning idiosyncratic cost parameters. This pattern of responses is the opposite of that estimated in Table 5: low production-plan announcements by a rival tend to cause rivals to contract rather than expand output. Hence, firms are not likely to be sharing information about idiosyncratic costs through their production-plan announcements, lending further support to the notion that they are sharing information about common demand parameters.

It is also worth noting that, in view of the estimates for $d_{i}^{5}$, the higher one's forecast- 
ed production, the more likely a firm will underbuild compared to its initial production plan. The coefficients are uniformly negative and significant for it own initial production plan. Moreover, the longer the plan horizon, the more negative are the errors, though the parameter estimate for the quadratic term suggests that the effect of the horizon is less pronounced as the horizon grows.

\section{Conclusion}

The results strongly reject the hypothesis that production plan announcements by the Big Four (and by the Big Three after the exit of $\mathrm{AMC}$ ) have no information content. The results also reject the hypothesis that there is no strategic response by firms to the announcements. Among the remaining alternatives, it is difficult to separate static (pure information sharing) motives from dynamic (collusive) motives. The results reveal a strong complementarily exhibited by firms' responses to rivals' announcements: firms react to larger-than-average plans of competitors by revising their own plans upward and by increasing their production relative to initial plans. This complementarily supports the hypothesis that production plan announcements contain information about common demand parameters. It is evidence agains the hypothesis that the announcements contain information about idiosyncratic cost parameters. One implication of the finding is that firms have little incentive to overstate their intended production levels in their plans, for this will induce rivals to produce more rather than contract their output.

It is possible that the dynamic pattern of firms' announcements is communication for the purpose of facilitating collusion, for example allowing GM to issue warning signals to smaller firms whose production plan announcements diverge from acceptable levels. This hypothesis is supported by the fact that GM responds positively to rivals' announcements with'its revisions, though there is little evidence that firm reduce their plans in response to warnings by GM. It is unlikely that communication works as modeled in Gertner (1993). In Gertner's model, firms start out with high prices and bid down to the low-cost firm's 
optimal price. In terms of quantities, this would mean that firms announce higher and higher quantities. By contrast, the data suggests that there is substantial overstatement of production the earlier is the announcement.

One caveat is that the automakers produce lines of differentiated products rather than a homogeneous "car" as the plans would indicate. Such aggregation would seem to reduce the value of the announcements relative to their value if they were disaggregated into more narrow categories. The results suggest that there is still information content even to these aggregate announcements. Arother caveat in interpreting the results is that production plan announcements represent only a small part of the total information flow among automakers. During the period studied, firms exchanged information on plant operations, ten-day sales, product improvements, etc. There may be motives for the broad sweep of information exchange that are not revealed in the analysis of any one piece.

There are a number of further questions that could be answered using the data set. Do firms establish reputations for honesty over time which they "harvest" when strategically beneficial? Such behavior would be in evidence if rivals' strategic reponses to a given firm's revisions are less pronounced the larger the firm's recent production plan errors. Do firms respond symmetrically to positive and negative revisions of competitors? Besides answering questions of interest to corporate strategists, identifying stable patterns in firms' production announcements would aid in forecasting trends in auto production, an important component of cyclical movements in the overall economy. Some work along these lines was pursued by Krane and Reifschneider (1988) with production plan announcements aggregated across automakers. I mprovements to the forecasts could come from disaggregating the plan announcements and taking into account firms strategic responses to competitors' plans. 


\section{References}

Berndt, Ernst R., Ann F. Friedlaender, and J udy Shaw-Er Wang Chiang.(1990) "Interdependent Pricing and Markup Behavior: An Empirical Analysis of GM, Ford, and Chrysler," NBER Working Paper no. 3396.

Bresnahan, Timothy. (1981) "Competition and Collusion in the American Automobile Industry: The 1955 Price War," J ournal of Industrial Economics 35: 457-482.

Bresnahan, Timothy, and Valerie Ramey. (1994) "Output Fluctuations at the Plant Level," Quarterly J ournal of Economics 109:593-624.

Cason, Timothy N.(1994) "The Impact of Information Sharing Opportunities on Market Outcomes: An Experimental Study," Southern Economic J ournal 61:18-39.

Cason, Timothy N. and Douglas D.Davis. (1995) "Price Communications in a MultiMarket Context: An Experimental Investigation," Review of Industrial Organization 10: 769-787.

Christensen, Laurits Rolf and Richard E.Caves.(1996) "Cheap Talk and Investment Rivalry in the Pulp and Paper Industry," Harvard University mimeo.

Clarke, Richard N.(1983) "Collusion and the Incentives for Information Sharing," Bell J ournal of Economics 14:383-394.

Crawford, Vincent P. and J oel Sobel.(1982) "Strategic Information Transmission," Econometrica, Vol. 50, No. 6, November, 1431-1451.

Ellison, Glenn.(1994)"Theories of Cartel Stability and the J oint Executive Committee," Rand J ournal of Economics 25:37-57.

Farrell, J oseph and Matthew Rabin. (1996) "Cheap Talk," J ournal of Economic Perspectives.

Gal-Or, Ester. (1985) "Information Sharing in Oligopoly," Econometrica 53:329-343.

Gertner, Robert.(1993) "The Role of Firm Asymmetries for Tacit Collusion in Markets with Immediate Competitive Responses," University of Chicago Graduate School of Business mimeo.

Green, Edward J. and Robert H.Porter.(1984)"Non-cooperative Collusion Under Imperfect Price Information," Econometrica 52: 87-100.

Grether, David M. and Charles R.Plott. (1984) "The Effect of Market Practices in Oligopolistic Markets: An Experimental Examination of the Ethyl Case," Economic Inquiry 22:479-507. 
Kahn, J ames A.(1992) "Why Is Production More Volatile Than Sales? Theory and Evidence on the Stockout-A voidance Motive for Inventory-Holding," Quarterly J ournal of Economics 107:481-510.

Kirby, Alison J. (1988) "Trade Associations as Information Exchange Mechanisms," Rand J ournal of Economics 19:138-146.

Krane, Spencer and David Reifschneider.(1987) "The Forecasting Accuracy of Auto Assembly Schedules," Federal Reserve Board of Governors mimeo.

Kühn, Kai-Uwe and Xavier Vives.(1994) "Information Exchanges Among Firms and Their Impact on Competition," Institut d'Anàlisi Econòmica, Barcelona, mimeo.

Maleug, David A. and Shunichi O. Tsutsui.(1996) "Duopoly Information Exchange: The Case of Unknown Slope," International J ournal of Industrial Organization 14: 119136.

Novshek, William and Hugo Sonnenschein.(1982)"Fulfilled Expectations Cournot Duopoly with Information Acquisition and Release," Bell J ournal of Economics 13:214-218.

Porter, Robert H.(1983) "Optimal Cartel Trigger Price Strategies," J ournal of Economic Theory 29:313-338.

Shapiro, Carl. (1986) "Exchange of Cost Information in Oligopoly," Review of Economic Studies 53:433-446.

Vives, Xavier. (1984) "Duopoly Information Equilibrium: Cournot and Bertrand," J ournal of Economic Theory 34:71-94.

Ward's Automotive Yearbook. various years.

Ward's Automotive Reports. various issues.

Ziv, Amir. (1993) "Information Sharing in Oligopoly: The Truth-Telling Problem," Rand J ournal of Economics 24:455-465. 
Table 1: Descriptive Statistics on Car Operations of the Big Four

\begin{tabular}{|c|c|c|c|c|c|}
\hline & & GM & Ford & Chrysler & $\mathrm{AMC}^{d}$ \\
\hline \multicolumn{6}{|c|}{ 1965-1978 Period } \\
\hline $\begin{array}{l}\text { Monthly } \\
\text { Production }^{a}\end{array}$ & $\begin{array}{l}\mu= \\
\sigma=\end{array}$ & $\begin{array}{c}375.3 \\
(112.0)\end{array}$ & $\begin{array}{c}187.1 \\
(48.0)\end{array}$ & $\begin{array}{l}110.4 \\
(29.7)\end{array}$ & $\begin{array}{l}22.2 \\
(8.7)\end{array}$ \\
\hline $\begin{array}{l}\text { Monthly } \\
\text { Prod. Plans }\end{array}$ & $\begin{array}{l}\mu= \\
\sigma=\end{array}$ & $\begin{array}{c}392.2 \\
(104.6)\end{array}$ & $\begin{array}{c}192.2 \\
(43.3)\end{array}$ & $\begin{array}{l}112.7 \\
(28.6)\end{array}$ & $\begin{array}{l}23.5 \\
(9.2)\end{array}$ \\
\hline $\begin{array}{l}\text { Monthly } \\
\text { Sales }^{a}\end{array}$ & $\begin{array}{l}\mu= \\
\sigma=\end{array}$ & $\begin{array}{l}373.1 \\
(77.2)\end{array}$ & $\begin{array}{l}195.0 \\
(34.6)\end{array}$ & $\begin{array}{l}111.9 \\
(20.2)\end{array}$ & $\begin{array}{l}22.7 \\
(6.2)\end{array}$ \\
\hline $\begin{array}{l}\text { Monthly } \\
\text { Inventories }^{a}\end{array}$ & $\begin{array}{l}\mu= \\
\sigma=\end{array}$ & $\begin{array}{c}709.2 \\
(156.4)\end{array}$ & $\begin{array}{l}422.8 \\
(77.2)\end{array}$ & $\begin{array}{l}301.7 \\
(38.7)\end{array}$ & $\begin{array}{c}66.8 \\
(14.2)\end{array}$ \\
\hline $\begin{array}{l}\text { Market } \\
\text { Share }^{b}\end{array}$ & $\begin{array}{l}\mu= \\
\sigma=\end{array}$ & $\begin{array}{l}41.4 \\
(4.3)\end{array}$ & $\begin{array}{l}21.7 \\
(2.0)\end{array}$ & $\begin{array}{l}12.5 \\
(1.8)\end{array}$ & $\begin{array}{c}2.6 \\
(0.7)\end{array}$ \\
\hline $\begin{array}{r}\% \text { Months St } \\
\text { Ge }\end{array}$ & $\begin{array}{l}\text { trikes } \\
\text { UAW }\end{array}$ & $\begin{array}{l}27.4 \\
3.5\end{array}$ & $\begin{array}{l}15.3 \\
2.4\end{array}$ & $\begin{array}{l}6.5 \\
0.6\end{array}$ & $\begin{array}{l}5.4 \\
2.4\end{array}$ \\
\hline \multicolumn{6}{|c|}{ 1979-1995 Period } \\
\hline $\begin{array}{l}\text { Monthly } \\
\text { Production }^{a}\end{array}$ & $\begin{array}{l}\mu= \\
\sigma=\end{array}$ & $\begin{array}{l}286.6 \\
(90.8)\end{array}$ & $\begin{array}{l}128.6 \\
(34.2)\end{array}$ & $\begin{array}{c}69.1 \\
(28.4)\end{array}$ & $\begin{array}{l}11.2 \\
(5.8)\end{array}$ \\
\hline $\begin{array}{l}\text { Monthly } \\
\text { Prod. Plans }\end{array}$ & $\begin{array}{l}\mu= \\
\sigma=\end{array}$ & $\begin{array}{l}299.9 \\
(92.4)\end{array}$ & $\begin{array}{l}132.8 \\
(38.8)\end{array}$ & $\begin{array}{c}71.4 \\
(28.7)\end{array}$ & $\begin{array}{l}11.7 \\
(5.8)\end{array}$ \\
\hline $\begin{array}{l}\text { Monthly } \\
\text { Sales }^{a}\end{array}$ & $\begin{array}{l}\mu= \\
\sigma=\end{array}$ & $\begin{array}{l}304.5 \\
(72.2)\end{array}$ & $\begin{array}{l}152.0 \\
(29.4)\end{array}$ & $\begin{array}{c}70.9 \\
(17.6)\end{array}$ & $\begin{array}{l}11.3 \\
(4.4)\end{array}$ \\
\hline $\begin{array}{l}\text { Monthly } \\
\text { Inventories }\end{array}$ & $\begin{array}{l}\mu= \\
\sigma=\end{array}$ & $\begin{array}{c}760.1 \\
(170.2)\end{array}$ & $\begin{array}{r}397.4 \\
(80.8)\end{array}$ & $\begin{array}{l}200.4 \\
(51.4)\end{array}$ & $\begin{array}{c}37.4 \\
(10.6)\end{array}$ \\
\hline $\begin{array}{l}\text { Market } \\
\text { Share }^{b}\end{array}$ & $\begin{array}{l}\mu= \\
\sigma=\end{array}$ & $\begin{array}{l}41.1 \\
(6.9)\end{array}$ & $\begin{array}{l}20.5 \\
(1.7)\end{array}$ & $\begin{array}{c}9.5 \\
(1.4)\end{array}$ & $\begin{array}{c}1.5 \\
(0.6)\end{array}$ \\
\hline$\%$ Months St & $\begin{array}{l}\text { trikes } \\
\text { UAW }\end{array}$ & $\begin{array}{l}6.9 \\
0.0\end{array}$ & $\begin{array}{l}1.5 \\
0.0\end{array}$ & $\begin{array}{l}2.5 \\
0.0\end{array}$ & $\begin{array}{l}0.5 \\
0.0\end{array}$ \\
\hline
\end{tabular}

Notes: $\mu$ is the mean and $\sigma$ the standard deviation. ${ }^{a}$ Measured in thousand cars ${ }^{b}$ Firm's car sales as a percentage of all car sales in the U.S. (both foreign and domestically-produced). ${ }^{c}$ Measured as the number of months in which there was strike activity of any duration of the stated type divided by total number of months in the period, expressed as a percent. ${ }^{d}$ The AMC statistics are for data up to the end of 1985. 
Table 2: Descriptive Statistics for Production Plan Errors

\begin{tabular}{|c|c|c|c|c|c|c|c|}
\hline & & \multicolumn{6}{|c|}{ Horizon } \\
\hline & & Negative $^{a}$ & $\begin{array}{c}<\text { One } \\
\text { Month }^{a}\end{array}$ & $\begin{array}{c}\text { One } \\
\text { Month }^{a}\end{array}$ & $\begin{array}{c}\text { Two } \\
\text { Months }^{a}\end{array}$ & $\begin{array}{c}>\text { Two } \\
\text { Months }^{a}\end{array}$ & $\begin{array}{l}\text { Pooled } \\
\text { Horizons }\end{array}$ \\
\hline \multicolumn{8}{|c|}{$P P E$ (error level, thousand cars) ${ }^{b}$} \\
\hline GM & $\begin{array}{c}\mu= \\
\sigma= \\
N=\end{array}$ & $\begin{array}{c}-0.5 \\
(5.9) \\
266\end{array}$ & $\begin{array}{c}-7.3 \\
(13.6) \\
240\end{array}$ & $\begin{array}{c}-13.7 \\
(30.0) \\
363\end{array}$ & $\begin{array}{c}-20.9 \\
(33.6) \\
364\end{array}$ & $\begin{array}{c}-24.1 \\
(46.6) \\
653\end{array}$ & $\begin{array}{c}-16.0 \\
(35.2) \\
1,886\end{array}$ \\
\hline Ford & $\begin{aligned} \mu & = \\
\sigma & = \\
N & =\end{aligned}$ & $\begin{array}{c}0.1 \\
(6.1) \\
266\end{array}$ & $\begin{array}{c}-2.5 \\
(10.8) \\
240\end{array}$ & $\begin{array}{c}-5.7 \\
(21.4) \\
363\end{array}$ & $\begin{array}{c}-8.6 \\
(21.1) \\
364\end{array}$ & $\begin{array}{c}-5.0 \\
(26.9) \\
653\end{array}$ & $\begin{array}{c}-4.8 \\
(21.2) \\
1,886\end{array}$ \\
\hline Chrysler & $\begin{aligned} \mu & = \\
\sigma & = \\
N & =\end{aligned}$ & $\begin{array}{c}0.3 \\
(2.4) \\
266\end{array}$ & $\begin{array}{c}-0.1 \\
(4.9) \\
240\end{array}$ & $\begin{array}{c}-1.9 \\
(10.2) \\
363\end{array}$ & $\begin{array}{c}-3.7 \\
(10.7) \\
364\end{array}$ & $\begin{array}{c}-3.6 \\
(14.9) \\
653\end{array}$ & $\begin{array}{c}-2.3 \\
(11.2) \\
1,886\end{array}$ \\
\hline $\mathrm{AMC}$ & $\begin{aligned} \mu & = \\
\sigma & = \\
N & =\end{aligned}$ & $\begin{array}{c}0.1 \\
(1.2) \\
182\end{array}$ & $\begin{array}{c}-0.3 \\
(2.3) \\
182\end{array}$ & $\begin{array}{c}-1.1 \\
(3.6) \\
260\end{array}$ & $\begin{array}{c}-1.8 \\
(3.6) \\
240\end{array}$ & $\begin{array}{c}-2.0 \\
(4.6) \\
437\end{array}$ & $\begin{array}{l}-1.3 \\
(3.7) \\
1,301\end{array}$ \\
\hline Pooled Firms & $\begin{array}{c}\mu= \\
\sigma= \\
N=\end{array}$ & $\begin{array}{c}0.0 \\
(4.7) \\
980\end{array}$ & $\begin{array}{c}-2.7 \\
(9.8) \\
902\end{array}$ & $\begin{array}{c}-5.9 \\
(20.5) \\
1,349\end{array}$ & $\begin{array}{c}-9.4 \\
(22.8) \\
1,332\end{array}$ & $\begin{array}{c}-9.2 \\
(30.6) \\
2,396\end{array}$ & $\begin{array}{c}-6.5 \\
(23.0) \\
6,959\end{array}$ \\
\hline \multicolumn{8}{|c|}{$Z P P E$ (percentage error) $^{b}$} \\
\hline GM & $\begin{aligned} \mu & = \\
\sigma & = \\
N & =\end{aligned}$ & $\begin{array}{c}-0.2 \\
(3.3) \\
266\end{array}$ & $\begin{array}{c}-2.5 \\
(4.7) \\
240\end{array}$ & $\begin{array}{c}-5.1 \\
(13.0) \\
363\end{array}$ & $\begin{array}{c}-7.4 \\
(12.9) \\
364\end{array}$ & $\begin{array}{c}-8.0 \\
(18.3) \\
653\end{array}$ & $\begin{array}{c}-5.5 \\
(13.9) \\
1,886\end{array}$ \\
\hline Ford & $\begin{array}{c}\mu= \\
\sigma= \\
N=\end{array}$ & $\begin{array}{c}0.0 \\
(3.2) \\
265\end{array}$ & $\begin{array}{c}-1.8 \\
(8.0) \\
240\end{array}$ & $\begin{array}{c}-4.5 \\
(16.8) \\
363\end{array}$ & $\begin{array}{c}-7.3 \\
(17.0) \\
364\end{array}$ & $\begin{array}{c}-4.8 \\
(22.7) \\
653\end{array}$ & $\begin{array}{c}-4.2 \\
(17.4) \\
1,885\end{array}$ \\
\hline Chrysler & $\begin{array}{c}\mu= \\
\sigma= \\
N=\end{array}$ & $\begin{array}{c}0.2 \\
(2.8) \\
266\end{array}$ & $\begin{array}{c}-0.1 \\
(6.8) \\
240\end{array}$ & $\begin{array}{c}-2.3 \\
(12.2) \\
363\end{array}$ & $\begin{array}{c}-6.5 \\
(17.0) \\
364\end{array}$ & $\begin{array}{c}-5.7 \\
(26.9) \\
653\end{array}$ & $\begin{array}{c}-3.6 \\
(18.7) \\
1,886\end{array}$ \\
\hline $\mathrm{AMC}$ & $\begin{aligned} \mu & = \\
\sigma & = \\
N & =\end{aligned}$ & $\begin{array}{c}0.5 \\
(8.5) \\
180\end{array}$ & $\begin{array}{c}-3.4 \\
(24.3) \\
182\end{array}$ & $\begin{array}{c}-7.4 \\
(26.1) \\
258\end{array}$ & $\begin{array}{c}-17.0 \\
(30.3) \\
239\end{array}$ & $\begin{array}{c}-19.6 \\
(45.8) \\
437\end{array}$ & $\begin{array}{l}-11.6 \\
(34.1) \\
1,296\end{array}$ \\
\hline Pooled Firms & $\begin{aligned} \mu & = \\
\sigma & = \\
N & =\end{aligned}$ & $\begin{array}{c}0.1 \\
(4.6) \\
977\end{array}$ & $\begin{array}{c}-1.8 \\
(12.5) \\
902\end{array}$ & $\begin{array}{c}-4.6 \\
(17.2) \\
1,347\end{array}$ & $\begin{array}{c}-8.8 \\
(19.5) \\
1,331\end{array}$ & $\begin{array}{c}-8.6 \\
(29.0) \\
2,396\end{array}$ & $\begin{array}{c}-5.8 \\
(21.3) \\
6,953\end{array}$ \\
\hline
\end{tabular}

Notes: $\mu$ is the mean, $\sigma$ the standard deviation $s$ nd $N$ the number of observations. ${ }^{a}$ The "negative" column refers to data with an horizon from -15 to $\mathrm{O}$ days, " $<$ one month" 1 to 25 days, "one month" 26 to 39 davs. "two months" 40 to 69 days, and " $>$ two months" 70 or more days. ${ }^{b} P P E$ equals $Q-P$, where $\mathbf{Q}$ is actual production and $P$ is the production plan; $Z P P E$ equals $100(Q-P) /\left[\frac{1}{2}(Q+P)\right]$. 
Table 3: Determinants of First Revision of Production Plan

\begin{tabular}{|c|c|c|c|c|c|c|c|}
\hline & \multicolumn{2}{|c|}{ GM } & \multicolumn{2}{|c|}{ Ford } & \multicolumn{2}{|c|}{ Chrysler } & \multirow{2}{*}{$\begin{array}{l}\mathrm{AMC} \\
\text { incl . } \\
\mathrm{AMC}\end{array}$} \\
\hline & $\begin{array}{l}\text { incl. } \\
\text { AMC }\end{array}$ & $\begin{array}{l}\text { excl. } \\
\text { AMC }\end{array}$ & $\begin{array}{l}\text { incl. } \\
\text { AMC }\end{array}$ & $\begin{array}{l}\text { excl. } \\
\text { AMC }\end{array}$ & $\begin{array}{l}\text { incl. } \\
\text { AMC }\end{array}$ & $\begin{array}{l}\text { excl. } \\
\text { AMC }\end{array}$ & \\
\hline $\begin{array}{l}\text { Own Initial } \\
\text { Prod. Plan }\end{array}$ & $\begin{array}{l}-0.112^{* * *} \\
(0.032)\end{array}$ & $\begin{array}{l}-0.058^{* *} \\
(0.019)\end{array}$ & $\begin{array}{l}-0.089^{* * *} \\
(0.031)\end{array}$ & $\begin{array}{l}-0.118^{* *} \\
(0.026)\end{array}$ & $\begin{array}{c}-0.056 \\
(0.039)\end{array}$ & $\begin{array}{l}-0.048^{*} \\
(0.029)\end{array}$ & $\begin{array}{c}0.034 \\
(0.029)\end{array}$ \\
\hline $\begin{array}{l}\text { Rival Initial } \\
\text { Prod. Plan }\end{array}$ & & & & & & & \\
\hline GM & & & $\begin{array}{c}0.032^{* *} \\
(0.016)\end{array}$ & $\begin{array}{r}0.016^{*} \\
(0.010)\end{array}$ & $\begin{array}{c}-0.007 \\
(0.014)\end{array}$ & $\begin{array}{c}-0.001 \\
(0.009)\end{array}$ & $\begin{array}{c}0.005 \\
(0.004)\end{array}$ \\
\hline Ford & $\begin{array}{c}0.196^{* *} \\
(0.063)\end{array}$ & $\begin{array}{c}0.134^{* * *} \\
(0.048)\end{array}$ & - & & $\begin{array}{c}0.039 \\
(0.028)\end{array}$ & $\begin{array}{r}0.040^{*} \\
(0.022)\end{array}$ & $\begin{array}{l}-0.013 \\
(0.008)\end{array}$ \\
\hline Chrysler & $\begin{array}{c}0.002 \\
(0.089)\end{array}$ & $\begin{array}{l}-0.004 \\
(0.063)\end{array}$ & $\begin{array}{c}0.086^{* *} \\
(0.044)\end{array}$ & $\begin{array}{c}0.073^{* *} \\
(0.035)\end{array}$ & - & - & $\begin{array}{c}0.003 \\
(0.011)\end{array}$ \\
\hline $\mathrm{AMC}$ & $\begin{array}{l}-0.339 \\
(0.226)\end{array}$ & - & $\begin{array}{l}-0.123 \\
(0.112)\end{array}$ & - & $\begin{array}{c}-0.017 \\
(0.101)\end{array}$ & - & \\
\hline Horizon & $\begin{array}{c}0.040 \\
(0.059)\end{array}$ & $\begin{array}{c}0.071 \\
(0.042)\end{array}$ & $\begin{array}{c}0.013 \\
(0.029)\end{array}$ & $\begin{array}{c}-0.001 \\
(0.023)\end{array}$ & $\begin{array}{c}0.035 \\
(0.026)\end{array}$ & $\begin{array}{c}0.043^{* *} \\
(0.019)\end{array}$ & $\begin{array}{c}0.003 \\
(0.008)\end{array}$ \\
\hline Constant & $\begin{array}{c}9.31 \\
(15.37)\end{array}$ & $\begin{array}{c}-11.62 \\
(8.81)\end{array}$ & $\begin{array}{l}-5.31 \\
(7.63)\end{array}$ & $\begin{array}{c}3.69 \\
(4.90)\end{array}$ & $\begin{array}{l}-5.57 \\
(6.83)\end{array}$ & $\begin{array}{l}-8.87 \\
(3.99)\end{array}$ & $\begin{array}{l}-1.14 \\
(1.99)\end{array}$ \\
\hline$N$ & 210 & 308 & 210 & 308 & 210 & 308 & 210 \\
\hline$R^{2}$ & 0.15 & 0.11 & 0.19 & 0.15 & 0.14 & 0.12 & 0.07 \\
\hline $\begin{array}{l}\text { Monthly } \\
\text { Dummies }\end{array}$ & 1.48 & $1.97^{* *}$ & $2.65^{* * *}$ & $2.62^{* * *}$ & $2.10^{* *}$ & $2.51^{* * *}$ & 0.96 \\
\hline
\end{tabular}

Notes: Seemingly unrelated regressions (SURs) with the dependent variable, first revision of the monthly production plan, defined formally as $R_{i t}^{+}-P_{i t}^{2}-P_{i t}^{1}$. The regressions that exclude AMC allow for longer time series (allowing data after the exit of AMC to be used). ${ }^{a}$ Formally, "own initial prod.plan" equals $P_{i t}^{1}$. Entries in the "Monthly dummies" row are $F$ statistics for the exclusion of the monthly dummies. $R^{2}$ corresponds to the individual OLS regressions from the first stage of the SUR procedure. Standard errors are given below coefficient estimates in parentheses. ${ }^{*}$ Significant at the ten percent level; ${ }^{* *}$ five percent level; ${ }^{* * *}$ one percent level. 
Table 4: Determinants of Second and Later Revisions of Production Plan

\begin{tabular}{|c|c|c|c|c|c|c|c|}
\hline & \multicolumn{2}{|c|}{ GM } & \multicolumn{2}{|c|}{ Ford } & \multicolumn{2}{|c|}{ Chrysler } & \multirow{2}{*}{$\begin{array}{l}\text { AMC } \\
\text { incl. } \\
\text { AMC }\end{array}$} \\
\hline & $\begin{array}{l}\text { incl. } \\
\text { AMC }\end{array}$ & $\begin{array}{l}\text { excl. } \\
\text { AMC }\end{array}$ & $\begin{array}{l}\text { incl. } \\
\text { AMC }\end{array}$ & $\begin{array}{l}\text { excl. } \\
\text { AMC }\end{array}$ & $\begin{array}{l}\text { incl. } \\
\text { AMC }\end{array}$ & $\begin{array}{l}\text { excl. } \\
\text { AMC }\end{array}$ & \\
\hline $\begin{array}{l}\text { Own Cumula- } \\
\text { tive Revision }\end{array}$ & $\begin{array}{c}0.003 \\
(0.023)\end{array}$ & $\begin{array}{l}-0.007 \\
(0.020)\end{array}$ & $\begin{array}{l}-0.076^{* *} \\
(0.030)\end{array}$ & $\begin{array}{l}-0.069^{* * *} \\
(0.023)\end{array}$ & $\begin{array}{l}-0.067^{* *} \\
(0.033)\end{array}$ & $\begin{array}{l}-0.066^{* *} \\
(0.026)\end{array}$ & $\begin{array}{l}-0.166^{* * *} \\
(0.035)\end{array}$ \\
\hline $\begin{array}{l}\text { Own Initial } \\
\text { Prod. Plan }\end{array}$ & $\begin{array}{l}-0.009 \\
(0.013)\end{array}$ & $\begin{array}{l}-0.021^{* * *} \\
(0.007)\end{array}$ & $\begin{array}{l}-0.014 \\
(0.013)\end{array}$ & $\begin{array}{l}-0.018 \\
(0.011)\end{array}$ & $\begin{array}{l}-0.040^{* *} \\
(0.018)\end{array}$ & $\begin{array}{l}-0.033^{* * *} \\
(0.012)\end{array}$ & $\begin{array}{l}-0.075^{* * *} \\
(0.013)\end{array}$ \\
\hline $\begin{array}{l}\text { Rival Cumula- } \\
\text { tive Revision }\end{array}$ & & & & & & & \\
\hline GM & - & & $\begin{array}{c}0.022 \\
(0.014)\end{array}$ & $\begin{array}{c}0.023^{* *} \\
(0.011)\end{array}$ & $\begin{array}{c}0.005 \\
(0.012)\end{array}$ & $\begin{array}{c}0.005 \\
(0.009)\end{array}$ & $\begin{array}{r}0.005^{*} \\
(0.003)\end{array}$ \\
\hline Ford & $\begin{array}{l}0.189^{* * *} \\
(0.050)\end{array}$ & $\begin{array}{l}0.161^{* * *} \\
(0.038)\end{array}$ & - & - & $\begin{array}{l}0.082^{* * *} \\
(0.025)\end{array}$ & $\begin{array}{l}0.059^{* * *} \\
(0.019)\end{array}$ & $\begin{array}{c}0.010 \\
(0.007)\end{array}$ \\
\hline Chrysler & $\begin{array}{l}-0.063 \\
(0.066)\end{array}$ & $\begin{array}{l}-0.054 \\
(0.053)\end{array}$ & $\begin{array}{c}0.082^{* *} \\
(0.038)\end{array}$ & $\begin{array}{c}0.069^{* *} \\
(0.031)\end{array}$ & - & - & $\begin{array}{l}-0.012 \\
(0.009)\end{array}$ \\
\hline $\mathrm{AMC}$ & $\begin{array}{l}-0.371 \\
(0.268)\end{array}$ & & $\begin{array}{l}-0.204 \\
(0.156)\end{array}$ & - & $\begin{array}{l}-0.229^{*} \\
(0.137)\end{array}$ & & \\
\hline Horizon & $\begin{array}{l}0.093^{* * *} \\
(0.023)\end{array}$ & $\begin{array}{l}0.084^{* * *} \\
(0.018)\end{array}$ & $\begin{array}{l}0.048^{* * *} \\
(0.014)\end{array}$ & $\begin{array}{c}0.049^{* * *} \\
(0.010)\end{array}$ & $\begin{array}{l}0.033^{* * *} \\
(0.011)\end{array}$ & $\begin{array}{l}0.035^{* * *} \\
(0.008)\end{array}$ & $\begin{array}{l}0.005^{* * *} \\
(0.003)\end{array}$ \\
\hline Constant & $\begin{array}{l}-9.05^{*} \\
(5.33)\end{array}$ & $\begin{array}{l}-3.70 \\
(3.08)\end{array}$ & $\begin{array}{l}-4.28 \\
(2.65)\end{array}$ & $\begin{array}{l}-2.62 \\
(1.97)\end{array}$ & $\begin{array}{l}-0.51 \\
(2.18)\end{array}$ & $\begin{array}{l}-1.02 \\
(1.38)\end{array}$ & $\begin{array}{l}-0.29 \\
(0.48)\end{array}$ \\
\hline$N$ & 624 & 914 & 624 & 914 & 624 & 914 & 624 \\
\hline$R^{2}$ & 0.10 & 0.09 & 0.06 & 0.06 & 0.07 & 0.06 & 0.13 \\
\hline $\begin{array}{l}\text { Monthly } \\
\text { Dummies }\end{array}$ & 1.22 & 1.54 & 1.50 & 1.34 & 0.57 & 1.26 & $2.16^{* *}$ \\
\hline
\end{tabular}

Notes: Seemingly unrelated regressions (SURs) in which the dependent variable (second and later revisions of the monthly production plan) is defined formally as $R_{i t}^{k}=P_{i t}^{k+1}-P_{i t}^{k}$. The regressions that exclude AMC allow for longer time series (allowing data after the exit of AMC to be used). "Cumulative revision" is defined as $C R_{i t}^{k}=\sum_{j=1}^{k-1} R_{i t}^{k}$, or equivalently, $C R_{i t}^{k}=P_{i t}^{k}-P_{i t}^{1}$. "Own initial prod. plan" equals $P_{i t}^{1}$, a $2 \mathrm{~d}$ "horizon" equals $H_{t}^{k}$. Entries in the "Monthly dummies" row are $F$ statistics for the exclusion of the monthly dummies. $K^{2}$ corresponds to the individual OLS regressions from the first stage of the SUR procedure. Standard errors are given below coefficient estimates in parentheses. ${ }^{*}$ Significant at the ten percent level; ${ }^{* *}$ five percent level; ${ }^{* * *}$ one percent level. 
Table 5: Relationship Between Production and One-Month-Ahead Plans

\begin{tabular}{|c|c|c|c|c|c|c|c|}
\hline & \multicolumn{2}{|c|}{ GM } & \multicolumn{2}{|c|}{ Ford } & \multicolumn{2}{|c|}{ Chrysler } & \multirow{2}{*}{$\begin{array}{l}\text { AMC } \\
\text { incl. } \\
\text { AMC }\end{array}$} \\
\hline & $\begin{array}{l}\text { incl. } \\
\text { AMC }\end{array}$ & $\begin{array}{l}\text { excl. } \\
\text { AMC }\end{array}$ & $\begin{array}{l}\text { incl. } \\
\text { AMC }\end{array}$ & $\begin{array}{l}\text { excl. } \\
\text { AMC }\end{array}$ & $\begin{array}{l}\text { incl. } \\
\text { AMC }\end{array}$ & $\begin{array}{l}\text { excl. } \\
\text { AMC }\end{array}$ & \\
\hline Own Plan & $\begin{array}{l}1.007^{* * *} \\
(0.041)\end{array}$ & $\begin{array}{c}0.963^{* * *} \\
(0.028)\end{array}$ & $\begin{array}{l}0.872^{* * *} \\
(0.059)\end{array}$ & $\begin{array}{l}0.903^{* * *} \\
(0.039)\end{array}$ & $\begin{array}{l}0.865^{* * *} \\
(0.038)\end{array}$ & $\begin{array}{l}0.895^{* * *} \\
(0.025)\end{array}$ & $\begin{array}{l}0.871^{* * *} \\
(0.026)\end{array}$ \\
\hline Own Strike & $\begin{array}{l}-26.65^{\text {*** }} \\
(6.19)\end{array}$ & $\begin{array}{l}-24.98^{* * *} \\
(4.91)\end{array}$ & $\begin{array}{l}-37.46^{* * *} \\
(5.20)\end{array}$ & $\begin{array}{l}-36.62^{* * *} \\
(4.53)\end{array}$ & $\begin{array}{l}-5.45^{*} \\
(2.92)\end{array}$ & $\begin{array}{l}-5.61^{* *} \\
(2.55)\end{array}$ & $\begin{array}{l}-5.835^{* * *} \\
(1.11)\end{array}$ \\
\hline \multicolumn{8}{|l|}{ Rival Plan } \\
\hline GM & & & $\begin{array}{l}0.087^{* * *} \\
(0.026)\end{array}$ & $\begin{array}{l}0.065^{* * *} \\
(0.017)\end{array}$ & $\begin{array}{l}-0.022^{*} \\
(0.013)\end{array}$ & $\begin{array}{l}-0.007 \\
(0.009)\end{array}$ & $\begin{array}{c}0.002 \\
(0.004)\end{array}$ \\
\hline Ford & $\begin{array}{c}0.026 \\
(0.082)\end{array}$ & $\begin{array}{c}0.045 \\
(0.065)\end{array}$ & & & $\begin{array}{l}0.093^{* * *} \\
(0.025)\end{array}$ & $\begin{array}{l}0.078^{* * *} \\
(0.020)\end{array}$ & $\begin{array}{c}0.010 \\
(0.008)\end{array}$ \\
\hline Chrysler & $\begin{array}{c}0.024 \\
(0.108)\end{array}$ & $\begin{array}{c}0.053 \\
(0.083)\end{array}$ & $\begin{array}{c}0.023 \\
(0.067)\end{array}$ & $\begin{array}{l}-0.017 \\
(0.051)\end{array}$ & & - & $\begin{array}{l}-0.007 \\
(0.010)\end{array}$ \\
\hline $\mathrm{AMC}$ & $\begin{array}{c}0.112 \\
(0.280)\end{array}$ & - & $\begin{array}{c}0.107 \\
(0.175)\end{array}$ & & $\begin{array}{c}0.036 \\
(0.086)\end{array}$ & - & - \\
\hline Horizon & $\begin{array}{l}-0.531 \\
(0.467)\end{array}$ & $\begin{array}{l}-0.443 \\
(0.363)\end{array}$ & $\begin{array}{l}-0.039 \\
(0.291)\end{array}$ & $\begin{array}{l}-0.130 \\
(0.222)\end{array}$ & $\begin{array}{c}0.052 \\
(0.142)\end{array}$ & $\begin{array}{c}0.127 \\
(0.110)\end{array}$ & $\begin{array}{l}-0.113^{* * *} \\
(0.044)\end{array}$ \\
\hline Constant & $\begin{array}{c}2.14 \\
(21.00)\end{array}$ & $\begin{array}{c}10.84 \\
(14.30)\end{array}$ & $\begin{array}{l}-12.62 \\
(13.04)\end{array}$ & $\begin{array}{l}-1.45 \\
(8.77)\end{array}$ & $\begin{array}{l}-5.57 \\
(6.39)\end{array}$ & $\begin{array}{l}-10.68^{* *} \\
(4.33)\end{array}$ & $\begin{array}{c}3.15 \\
(1.96)\end{array}$ \\
\hline$N$ & 257 & 357 & $257^{\circ}$ & 357 & 257 & 357 & 257 \\
\hline$R^{2}$ & 0.88 & 0.92 & $0.8 ?$ & 0.86 & 0.90 & 0.93 & 0.88 \\
\hline $\begin{array}{l}\text { Monthly } \\
\text { Dummies }\end{array}$ & 1.56 & $1.79^{*}$ & $2.47^{* * *}$ & $2.44^{* * *}$ & $2.70^{* * *}$ & $2.63^{* * *}$ & $2.96^{* * *}$ \\
\hline
\end{tabular}

Notes: OLS regressions of monthly firm production on various independent variables. OLS is equivalent to SUR in the present case since the independent variables are the same in each equation. The regressions that exclude AMC allow for longer time series (allowing data after the exit of AMC to be used). "Horizon" equals $H_{t}^{k}$. Entries in the "Monthly dummies" row are $F$ statistics for the exclusion of the monthly dummies. Standard errors are given in parentheses below coefficient estimates. ${ }^{*}$ Significant at the ten percent level; ${ }^{* *}$ five percent level; ${ }^{* * *}$ one percent level. 
Table 6: Effect of Strikes on Production Plan Errors

\begin{tabular}{|c|c|c|c|c|c|c|c|}
\hline & \multicolumn{2}{|c|}{ GM } & \multicolumn{2}{|c|}{ Ford } & \multicolumn{2}{|c|}{ Chrysler } & \multirow{2}{*}{$\begin{array}{l}\text { AMC } \\
\text { incl. } \\
\text { AMC }\end{array}$} \\
\hline & $\begin{array}{l}\text { incl. } \\
\text { AMC }\end{array}$ & $\begin{array}{l}\text { excl. } \\
\text { AMC }\end{array}$ & $\begin{array}{l}\text { incl. } \\
\mathrm{AMC}\end{array}$ & $\begin{array}{l}\text { excl. } \\
\text { AMC }\end{array}$ & $\begin{array}{l}\text { incl. } \\
\mathrm{AMC}\end{array}$ & $\begin{array}{l}\text { excl. } \\
\text { AMC }\end{array}$ & \\
\hline Own Strike & $\begin{array}{l}-15.06^{* * *} \\
(3.20)\end{array}$ & $\begin{array}{l}-13.22^{* * *} \\
(2.54)\end{array}$ & $\begin{array}{l}-35.386^{* * *} \\
(2.58)\end{array}$ & $\begin{array}{l}-33.91^{* * *} \\
(2.25)\end{array}$ & $\begin{array}{l}-2.45 \\
(1.65)\end{array}$ & $\begin{array}{l}-2.57^{*} \\
(1.43)\end{array}$ & $\begin{array}{l}-3.98^{* * *} \\
(0.70)\end{array}$ \\
\hline \multicolumn{8}{|l|}{ Rival Strike } \\
\hline GM & - & - & $\begin{array}{l}10.93^{* * *} \\
(1.94)\end{array}$ & $\begin{array}{l}11.63^{* * *} \\
(1.53)\end{array}$ & $\begin{array}{l}4.46^{* * *} \\
(1.06)\end{array}$ & $\begin{array}{l}2.85^{* * *} \\
(0.84)\end{array}$ & $\begin{array}{l}1.26^{* * *} \\
(0.30)\end{array}$ \\
\hline Ford & $\begin{array}{l}17.62^{* * *} \\
(4.40)\end{array}$ & $\begin{array}{l}17.94^{* * *} \\
(3.87)\end{array}$ & & - & $\begin{array}{c}0.88 \\
(1.42)\end{array}$ & $\begin{array}{c}1.24 \\
(1.27)\end{array}$ & $\begin{array}{c}0.78^{*} \\
(0.41)\end{array}$ \\
\hline Chrysler & $\begin{array}{c}2.09 \\
(5.13)\end{array}$ & $\begin{array}{c}2.67 \\
(4.39)\end{array}$ & $\begin{array}{c}0.20 \\
(3.01)\end{array}$ & $\begin{array}{c}2.55 \\
(2.55)\end{array}$ & - & - & $\begin{array}{c}0.30 \\
(0.47)\end{array}$ \\
\hline $\mathrm{AMC}$ & $\begin{array}{l}-0.247 \\
(7.71)\end{array}$ & - & $\begin{array}{l}9.52^{* *} \\
(4.59)\end{array}$ & - & $\begin{array}{l}-4.93^{* *} \\
(2.49)\end{array}$ & - & \\
\hline Horizon & $\begin{array}{l}-0.370^{* * *} \\
(0.057)\end{array}$ & $\begin{array}{l}-0.321^{* * *} \\
(0.041)\end{array}$ & $\begin{array}{l}-0.166^{* * *} \\
(0.034)\end{array}$ & $\begin{array}{l}-0.154^{* * *} \\
(0.024)\end{array}$ & $\begin{array}{l}-0.080^{* * *} \\
(0.018)\end{array}$ & $\begin{array}{l}-0.085^{* * *} \\
(0.014)\end{array}$ & $\begin{array}{l}-0.031^{* * *} \\
(0.005)\end{array}$ \\
\hline $\begin{array}{l}\text { Horizon }^{2} \\
\left(\times 10^{-3}\right)\end{array}$ & $\begin{array}{c}1.206^{* *} \\
(0.410)\end{array}$ & $\begin{array}{l}1.158^{* * *} \\
(0.302)\end{array}$ & $\begin{array}{l}0.986^{* * *} \\
(0.242)\end{array}$ & $\begin{array}{l}1.005^{* * *} \\
(0.176)\end{array}$ & $\begin{array}{l}0.430^{* * *} \\
(0.132)\end{array}$ & $\begin{array}{l}0.452^{* * *} \\
(0.099)\end{array}$ & $\begin{array}{l}0.090^{* * *} \\
(0.038)\end{array}$ \\
\hline $\begin{array}{l}\text { Own Prod. } \\
\text { Plan }\end{array}$ & $\begin{array}{l}-0.038^{* * *} \\
(0.014)\end{array}$ & $\begin{array}{l}-0.070^{* * *} \\
(0.009)\end{array}$ & $\begin{array}{l}-0.064^{* * *} \\
(0.014)\end{array}$ & $\begin{array}{l}-0.067^{* * *} \\
(0.012)\end{array}$ & $\begin{array}{l}-0.067^{* * *} \\
(0.012)\end{array}$ & $\begin{array}{l}-0.052^{* * *} \\
(0.009)\end{array}$ & $\begin{array}{l}-0.114^{* * *} \\
(0.010)\end{array}$ \\
\hline Constant & $\begin{array}{l}15.95^{* * *} \\
(5.92)\end{array}$ & $\begin{array}{l}21.44^{* * *} \\
(3.67)\end{array}$ & $\begin{array}{l}6.83^{* *} \\
(2.99)\end{array}$ & $\begin{array}{l}6.69^{* * *} \\
(2.21)\end{array}$ & $\begin{array}{c}0.40 \\
(1.58)\end{array}$ & $\begin{array}{c}1.00 \\
(1.11)\end{array}$ & $\begin{array}{l}1.29^{* * *} \\
(0.39)\end{array}$ \\
\hline $\mathrm{N}$ & 1,328 & 1.922 & 1,328 & 1,922 & 1,328 & 1,922 & 1,328 \\
\hline$R^{2}$ & 0.13 & 0.13 & 0.20 & 0.17 & 0.08 & 0.07 & 0.19 \\
\hline $\begin{array}{l}\text { Monthly } \\
\text { Dummies }\end{array}$ & $6.26^{* * *}$ & $8.84^{* * *}$ & $9 . \cup 9^{* * *}$ & $9.66^{* * *}$ & $6.71^{* * *}$ & $7.35^{* * *}$ & $9.85^{* * *}$ \\
\hline
\end{tabular}

Notes: Seemingly unrelated regressions (SURs) of production plan errors on various independent variables. The strike variables are dummies equal to one if the firm experienced-any strike activity in the given month. The regressions that exclude AMC allow for longer time series (allowing data after the exit of AMC to be used). "Own prod.plan"equals $P_{i t}^{k}$ and "horizon" equals $H_{t}^{k}$ (the superscript is the same $k$ as in the production Plan error). The Horizon ${ }^{2}$ coefficients have been multiplied by $10^{3}$. Entries in the "Monthly dummies" row are $F$ statistics for the exclusion of the monthly dummies. $R^{2}$ corresponds to the individual OLS regressions from the first stage of the SUR procedure. Standard errors are given below coefficient estimates in parentheses. ${ }^{*}$ Significant at the ten percent level; ${ }^{* *}$ five percent level; ${ }^{* * *}$ one percent level. 
Figure 1: Example Timeline of Plan Announcements

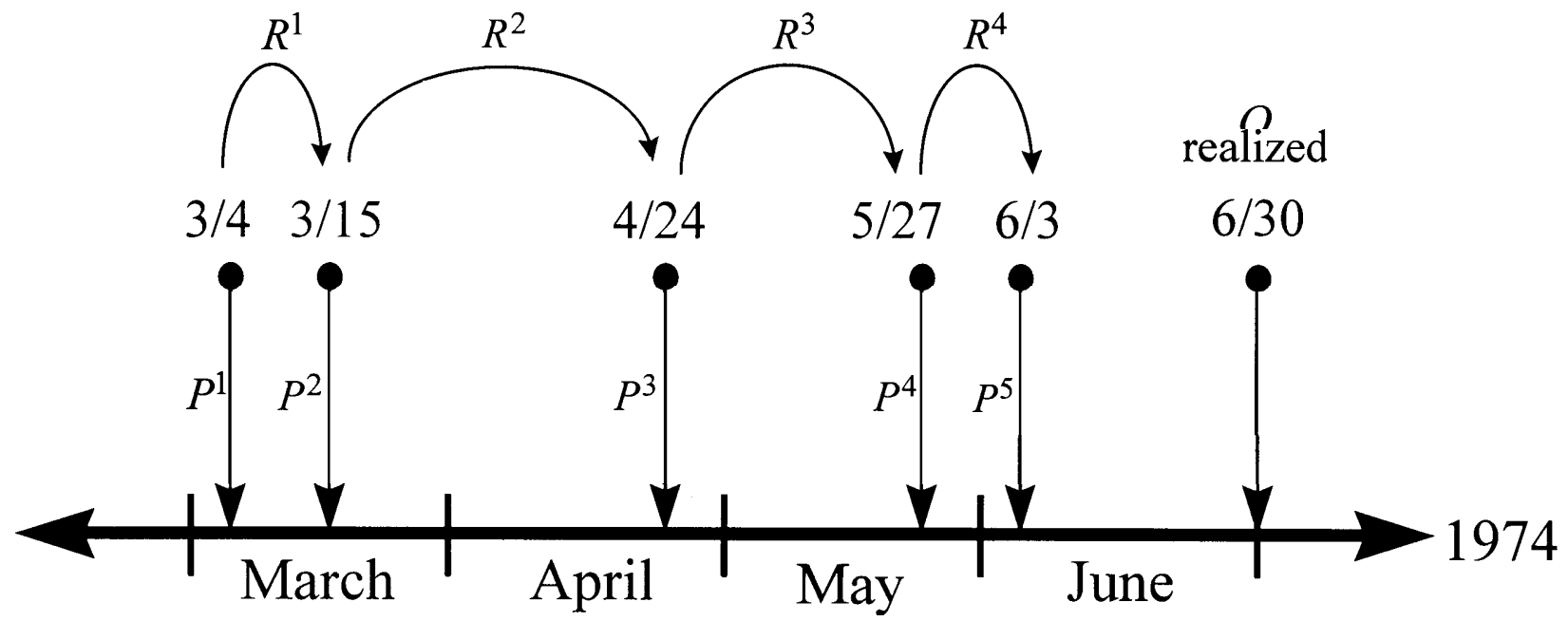

Note: In this example, plan announcements are for production in the month of June, 1974. 

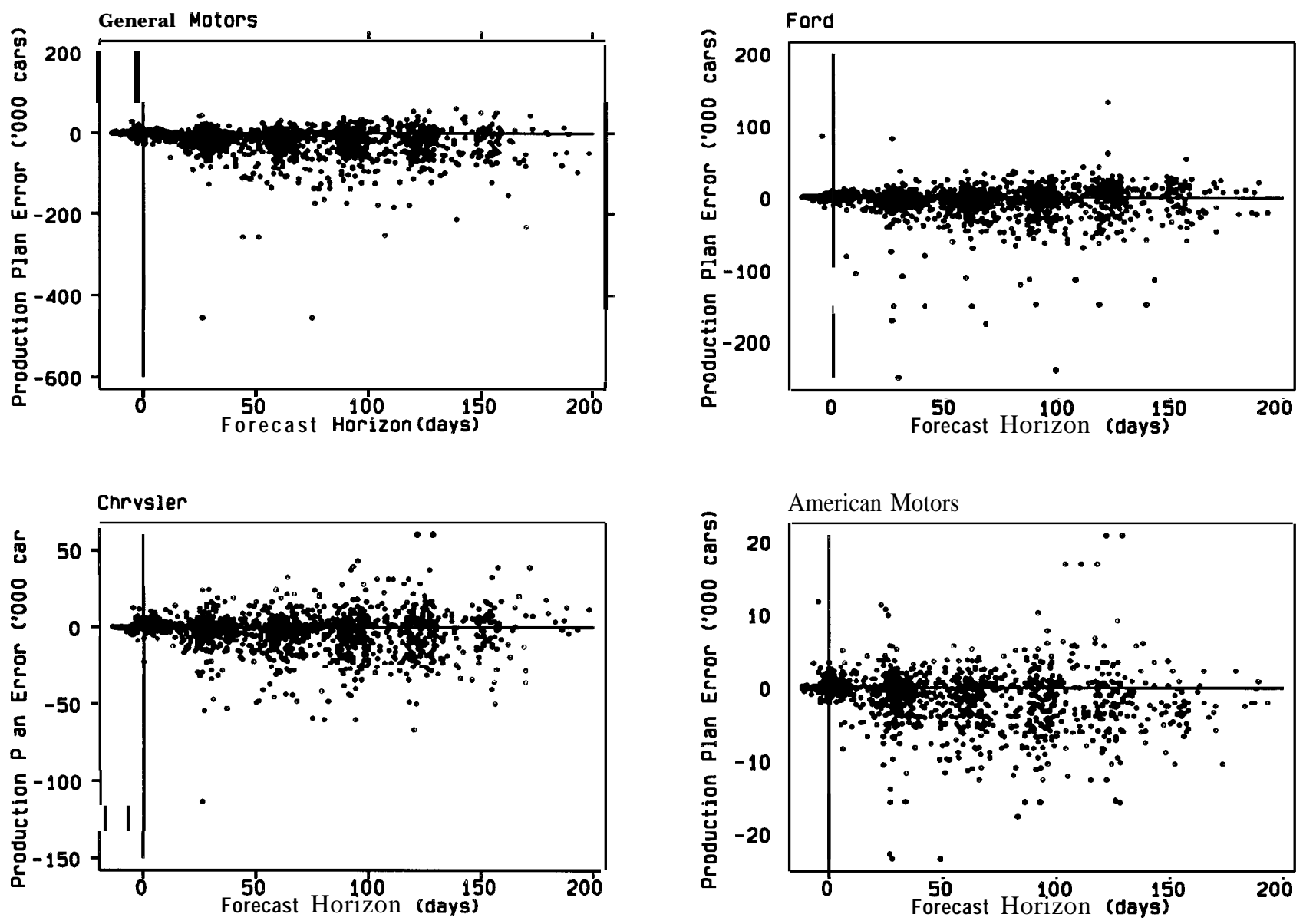

Fig. 2: Production Plan Errors by Firm, 1965-95 

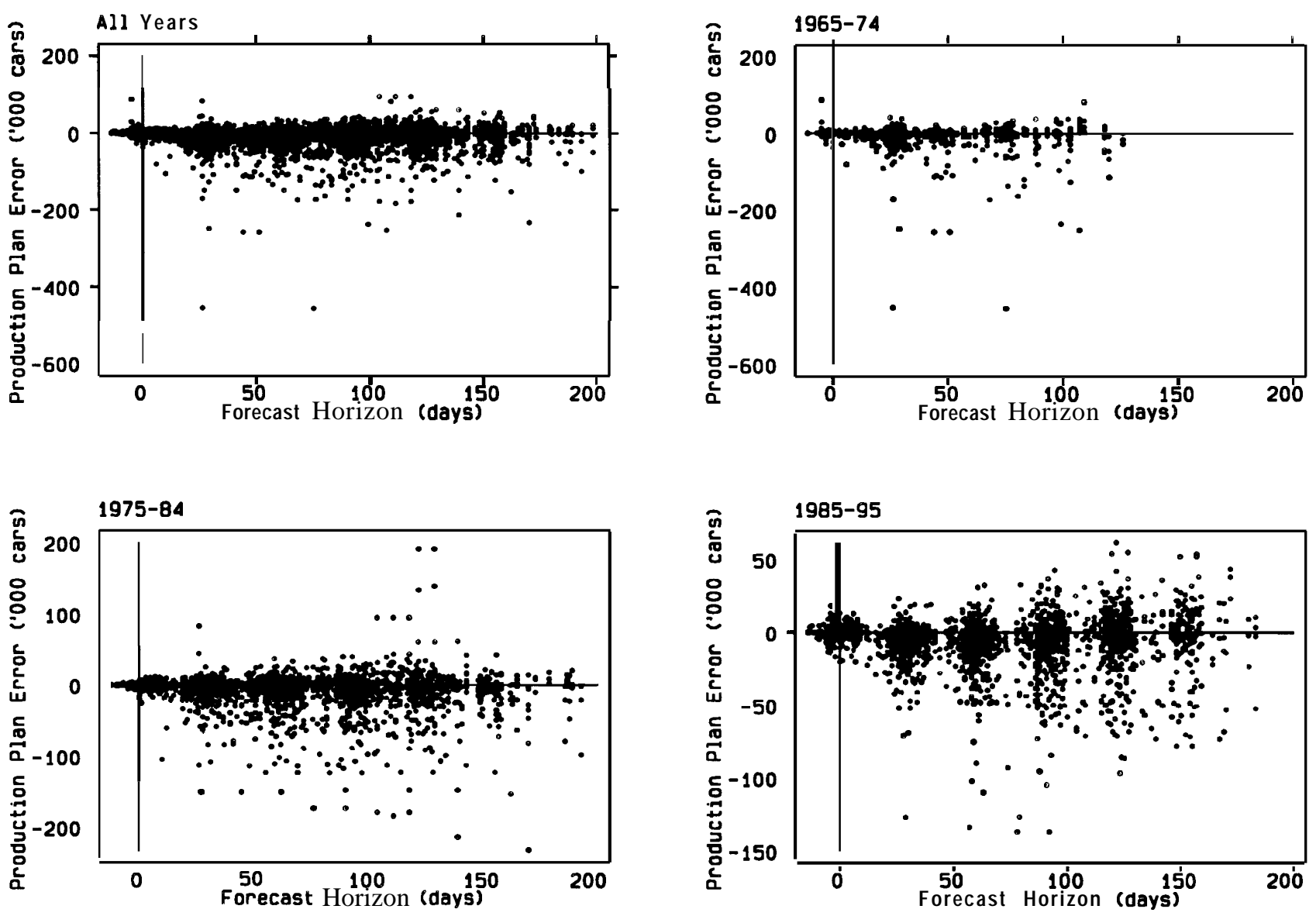

Fig.3: Producti on PI an Errors by Period, Big 4 Pooled, 1965-95 